\title{
Progesterone and oestrogen receptors in the decidualized mouse uterus and effects of different types of anti-progesterone treatment
}

\author{
Z. Parandoosh ${ }^{1 *}$, D. L. Crombie ${ }^{1}$, T. A. Tetzke ${ }^{1 *}, J^{\prime}$ S. Hayes ${ }^{1}$, \\ R. B. Heap ${ }^{2,3}$ and M-W. Wang ${ }^{1 \dagger}$ \\ ${ }^{1}$ Ligand Pharmaceuticals, Inc., 9393 Towne Centre Drive, San Diego, CA 92121, USA; \\ ${ }^{2}$ The Babraham Institute, Babraham, Cambridge CB2 4AT, UK; and ${ }^{3}$ School of Clinical Medicine, \\ University of Cambridge, Cambridge CB2 2SW, UK
}

\begin{abstract}
Pseudopregnant mice were treated systemically with monoclonal anti-progesterone antibody (DB3) (model 1), or progesterone receptor antagonists RU486 or ZK98,299 (ZK299) (model 2) on day 3 post coitum. On day 4, sesame oil was administered intraluminally into one uterine horn to induce decidualization. On day 7, the average mass of the oil-injected horn was $335.2 \pm 52.4 \mathrm{mg}$, eight times greater than that of the non-injected horn (40.8 $\pm 5.3 \mathrm{mg} ; P<0.001$ ). After treatment with DB3, RU486 or ZK299, the masses of the injected horns did not differ significantly from those of non-injected horns. In the control group, concentrations of progesterone receptors (ligand-binding assay) increased twofold in the decidualized $\left(52.2 \pm 7.4 \mathrm{fmol} \mathrm{mg}{ }^{-1}\right)$ compared with the non-injected horn $\left(26.0 \pm 7.6 \mathrm{fmol} \mathrm{mg}^{-1} ; P<0.05\right)$, whereas oestrogen receptor content (ligand-exchange assay) decreased by $53 \%\left(104.9 \pm 18.2\right.$ versus $\left.224.3 \pm 18.1 \mathrm{fmol} \mathrm{mg}^{-1} ; P<0.001\right)$. In model 1 , antibody-treated animals showed a tenfold increase in the concentration of progesterone receptors $\left(261.7 \pm 81.1 \mathrm{fmol} \mathrm{mg}^{-1} ; P<0.001\right)$, but there was no differential distribution of progesterone or oestrogen receptors in the oil-injected versus non-injected uterine horns. In model 2, uterine progesterone and oestrogen receptors again showed no differential response between injected and non-injected horns regardless of the route of administration (systemic or intraluminal). Concentrations of progesterone receptors in RU486-treated (35.8 $\pm 9.4 \mathrm{fmol} \mathrm{mg}^{-1}$ ) and ZK299-treated $\left(32.0 \pm 10.2 \mathrm{fmol} \mathrm{mg}^{-1}\right.$ ) mice were comparable to those in non-injected horns $\left(35.3 \pm 6.3\right.$ and $34.2 \pm 5.1 \mathrm{fmol} \mathrm{mg}^{-1}$, respectively) and were not significantly different from the control group (26.0 $\pm 7.6 \mathrm{fmol}$ $\mathrm{mg}^{-1}$ ). The results show that oil-induced decidualization is accompanied by increased concentrations of progesterone receptors and decreased concentrations of oestrogen receptors. When decidualization is blocked by anti-progesterone treatment (antibody against progesterone or progesterone receptor antagonist), there are differing effects on receptor responses with an increase in progesterone receptors and decrease in oestrogen receptors after passive immunization, and no change in progesterone receptors and a reduction in oestrogen receptors after anti-progestins. The anti-decidualization effect in the two models was therefore achieved via dissimilar uterine receptor responses.
\end{abstract}

\section{Introduction}

The primary dependence of uterine proliferation and differentiation on the co-ordinated effects of progesterone and oestradiol in early pregnancy is well established. The hormonal control of these events has been investigated in detail at the morphological, biochemical and molecular levels. Knowledge of these processes gives valuable insights into essential features of the successful establishment of pregnancy in mammals that

*Present address: Prizm Pharmaceuticals, Inc., 11035 Roselle Street, San Diego, CA 92121, USA.

${ }^{\dagger}$ Correspondence.

Received 12 May 1995 show a pronounced decidualization of the uterine stroma, as in rodents and humans (Psychoyos, 1973; Finn, 1977; Glasser, 1990; Abrahamson and Zorn, 1993; Tang et al., 1994).

Decidualization, initiated by an embryonic or artificial stimulus, depends upon previous sensitization by a sequence of oestrogen and progesterone secretion. In mice, preovulatory ovarian oestrogen stimulates uterine epithelial cell proliferation on days 1 and 2 of pregnancy; progesterone from the newly formed corpus luteum initiates the proliferation of stromal cells potentiated by increased secretion of oestrogen during the preimplantation period. Decidualization can be artificially induced in pseudopregnant females on day 4 . With the advent of anti-progestins, attention is currently focused on two topics: 
first the molecular mechanisms by which anti-progestins interrupt decidualization and, thereby, prevent the establishment of pregnancy; and second the cellular mechanisms involved, since there is growing evidence that paracrine or autocrine, as well as endocrine, pathways are used.

Expression of several genes in the endometrium has been shown to be regulated by progesterone (for example, c-myc, genes encoding uteroglobin, uteroferrin and calcitonin). A potential molecular mechanism associated with the process of decidualization was reported by Wang et al. (1994) and Zhang et al. (1994), namely, the local synthesis of mRNA for heparinbinding epidermal growth fractor (HB-EGF). In mice, the message for this growth factor is stimulated in epithelial cells by oestradiol and in stromal cells by progesterone and oestradiol (Wang et al., 1994). In rats, HB-EGF is stimulated in stromal cells by progesterone treatment and by an artificial decidual stimulus. The time interval from artificial stimulus to raised mRNA encoding HB-EGF is $8-24 \mathrm{~h}$ and corresponds to the period of maximum stromal mitotic activity. The antiprogestin ZK98,299 (ZK299) blocks decidualization and progesterone-induced expression of mRNA encoding HB-EGF (Zhang et al., 1994).

Steroid anti-progestins such as RU486 and ZK299, and antibodies against progesterone such as DB3 are highly effective as anti-implantation agents in laboratory models of implantation (Vinijsanun and Martin, 1990; Roblero and Croxatto, 1991; Wang and Heap, 1992). Anti-progestins interfere with receptor function either by inhibiting transcription factor activities (McDonnell et al., 1993) or by preventing receptor binding to the specific hormone responsive elements (Truss et al., 1994). Antibodies, however, act by ligand scavenging which significantly diminishes target organ responses (Rider et al., 1986; Wang and Heap, 1992).

The aim of the present study was to determine whether the distinct anti-decidualization mechanisms of antibodies against progesterone and anti-progestins result in similar or contrasting effects on uterine concentrations of progesterone and oestrogen receptors. The hypothesis is that anti-decidualization effects can be achieved by more than one route of receptor disruption. Our goal was set within a well-established framework of knowledge that uterine progesterone receptors are rapidly upregulated by oestradiol (Manni et al., 1981; Kraus and Kałzenellenbogen, 1993), uterine oestrogen receptors are downregulated by oestrogen (Manni et al., 198I; Shupnik et al., 1989) and progesterone (Hsueh et al., 1976; Pavlik and Coulson, 1976), and that progesterone will block oestradiolinduced progesterone receptor upregulation - a response that can be inhibited by simultaneous administration of the anti-progestin, RU486 (Kraus and Katzenellenbogen, 1993).

\section{Materials and Methods}

\section{Reagents}

Progesterone receptor antagonists RU486 (Mifepristone: Roussel-Uclaf, Romainville) and ZK299 (Onapristone: Schering AG, Berlin) were dissolved in sesame oil. Monoclonal antibody (IgGI) directed against progesterone (DB3) was prepared in $\mathrm{BALB} / \mathrm{c}$ mice and purified as described by Ellis et al. (1988).

\section{Animals}

Mature, virgin BALB/c mice (10-12 weeks old; Harlan Sprague Dawley Inc., Indianapolis, IN) were housed in a light, temperature-controlled room, with food and water ad libitum (Diet LM-485, Teklad, Madison, WI). Females were caged with vasectomized males of the same strain between 17:00 and 10:00 h. Pseudopregnancy was dated from the morning when a vaginal plug was detected (day I; Bronson et al., 1966).

\section{Decidualization}

Pseudopregnant mice were treated with $100 \mu g$ RU486 (s.c.), $100 \mu \mathrm{g}$ ZK299 (s.c.), or $9.0 \mathrm{nmol}$ (1.35 mg) DB3 (i.p.) at 10:00 h on day 3 (DB3 on day 2 for progesterone receptor measurements). Control animals received an equivalent volume of oil. On day $4(16: 00 \mathrm{~h}), 10 \mu \mathrm{l}$ sesame oil was injected intraluminally into the right uterine horn (injected) and the left horn was left undisturbed (non-injected control). In another series of experiments, the same quantity of RU486 or ZK299 was injected intraluminally into the right uterine horn. At necropsy (day 7), the uterine horns were removed, trimmed, blotted and weighed. The gain in uterine wet mass was calculated by subtracting the mass of the non-injected horn from that of the injected horn.

\section{Preparation of tissue extract for receptor binding}

Whole cell receptor extract was prepared in $50 \mathrm{mmol}$ Tris- $\mathrm{HCl}$ buffer $\mathrm{l}^{-1}(\mathrm{pH}=7.4)$ containing $30 \%(\mathrm{v} / \mathrm{v})$ glycerol, $1.0 \mathrm{mmol}$ EDTA $\mathrm{I}^{-1}, 12 \mathrm{mmol}$ monothioglycerol $\mathrm{l}^{-1}$, $1.0 \mathrm{mmol}$ phenylmethylsulfonyl (PMSF) fluoride-protease inhibitor $\mathrm{I}^{-1}$ and $0.5 \mathrm{~mol}$ potassium chloride $\mathrm{I}^{-1}(90-100 \mathrm{mg}$ uterine tissue $\mathrm{ml}^{-1}$ ). The preparation was incubated at $4^{\circ} \mathrm{C}$ for $60 \mathrm{~min}$ with resuspension every $10 \mathrm{~min}$. The suspension was centrifuged (105 $000 \mathrm{~g}$ for $45 \mathrm{~min}$ ) and the supernatant frozen and stored at $-70^{\circ} \mathrm{C}$ for subsequent binding studies as decribed below. An aliquot of the cell extract was taken for protein assay (Bradford, 1976).

\section{Oestrogen receptor assay}

After dilution (1.0 $\mathrm{mg} \mathrm{ml}^{-1}$ protein) with buffer $\mathrm{A}$ (10 mmol Tris- $\mathrm{HCl}$ buffer $1^{-1}, \mathrm{pH} 7.4$, containing $10 \%(\mathrm{v} / \mathrm{v})$ glycerol, $1.0 \mathrm{mmol}$ EDTA $\mathrm{I}^{-1}, 12 \mathrm{mmol}$ thioglycerol $\mathrm{I}^{-1}$ and $1.0 \mathrm{mmol}$ PMSF $\left.\mathrm{I}^{-1}\right)$, the uterine cell extracts $(250 \mu \mathrm{l})$ were incubated with $10 \mathrm{nmol}\left[{ }^{3} \mathrm{H}\right]$ oestradiol $1^{-1}$ (specific activity: $136 \mathrm{Ci}$ $\mathrm{mmol}^{-1}$; Amersham International, Amersham, Bucks) in the presence or absence of excess (200-fold) diethylstilboestrol (Sigma Chemical Co., St Louis, MO) for $60 \mathrm{~min}$ at $37^{\circ} \mathrm{C}$. The preparation was cooled to $4^{\circ} \mathrm{C}$ and an equal volume of hydroxylapatite (HAP) slurry (Ho et al., 1985) was added. After incubation for $30 \mathrm{~min}$, the mixture was centrifuged at $800 \mathrm{~g}$ and the supernatant discarded. The HAP pellet was washed with $2.0 \mathrm{ml} \mathrm{HAP}$-washing buffer $\left(10 \mathrm{mmol}\right.$ Tris- $\mathrm{HCl} 1^{-1}$, $\mathrm{pH}$ 7.4, $5.0 \mathrm{mmol}$ dithiothreitol $\mathrm{l}^{-1}$ and $1.0 \%(\mathrm{v} / \mathrm{v})$ Triton $\mathrm{X}-100$ ) and transferred to vials containing $10 \mathrm{ml}$ of scintillation fluid for radioactivity determination. The exchange condition measures the total oestrogen receptor content (occupied and 
unoccupied binding sites) (Anderson et al., 1972). The extent of binding was calculated based upon the specific activity of $\left[{ }^{3} \mathrm{H}\right]$ oestradiol and protein concentration.

\section{Progesterone receptor assay}

Uterine cell extracts ( $1.0 \mathrm{mg} \mathrm{ml}^{-1}$ protein; $200 \mu \mathrm{l}$ ) were incubated at $4^{\circ} \mathrm{C}$ for a minimum of $12 \mathrm{~h}$ with $10 \mathrm{nmol}$ $\left.{ }^{3} \mathrm{H}\right]$ progesterone $\mathrm{I}^{-1}$ (specific activity: $103 \mathrm{Ci} \mathrm{mmol}{ }^{-1}$; Amersham) in the presence or absence of excess (200-fold) cold progesterone (Sigma). Bound $\left[{ }^{3} \mathrm{H}\right]$ progesterone was determined using HAP as described above. Before the assay, samples from mice treated with DB3 were reacted with rabbit anti-mouse $\operatorname{IgG}$ at $4^{\circ} \mathrm{C}$ for $30 \mathrm{~min}$. The amount of anti-mouse $\operatorname{IgG}(0.1 \mu \mathrm{g}$ per $1.0 \mu \mathrm{g}$ extract) used was optimized to maximally precipitate DB3 from the system and minimize its interference with the binding assay. Radioactivity was determined with a liquidscintillation counter. The specific activity of $\left[{ }^{3} \mathrm{H}\right]$ progesterone and protein concentration were used for calculation of progesterone receptor content.

\section{Statistical analysis}

Pairwise statistical analyses were performed using two-tailed Student's $t$ test. Unless stated otherwise, all results are reported as means \pm SEM.

\section{Results}

\section{Effects of anti-progesterone treatment upon decidualization}

There was a marked increase in uterine mass in control females following a decidual stimulus (sesame oil) given on day 4 of pseudopregnancy (Table 1). Oil-injected horns displayed an eightfold increase in wet mass compared with non-injected horns $(335.2 \pm 52.4$ versus $40.8 \pm 5.3 \mathrm{mg} ; P<0.001)$ at day 7 of pseudopregnancy. Systemic injection (i.p. or s.c.) of DB3, RU486 or ZK299, or intraluminal administration of RU486 or ZK299, completely blocked decidualization $(P<0.001$; Table 1).

\section{Effects of anti-progesterone treatment on progesterone receptor concentration}

The concentration of progesterone receptors increased twofold after decidualization $(P<0.05 ;$ Fig. 1 ). In antibody-treated females, progesterone receptor concentration increased substantially compared with the control group in non-injected (tenfold, $P<0.001$ ) and injected (fivefold, $P<0.001$ ) uterine horns. The anti-progestins, RU486 and ZK299, had no effect on progesterone receptor concentrations in either horn when administered systemically (Fig. 1). Progesterone receptor concentration in both horns was similar following intraluminal injection of RU486 or ZK299 (data not shown).

\section{Effects of anti-progesterone treatment on oestrogen receptor concentration}

The concentration of oestrogen receptors in the control group decreased significantly $(53 \%)$ in the decidualized uterine horn $(P<0.001$; Fig. 2$)$. This decrease occurred in conjunction with an eightfold increase in tissue mass. A similar reduction in oestrogen receptor concentration occurred in injected and non-injected horns $(P<0.01$ to $P<0.001)$ after systemic treatment with DB3, RU486 or ZK299. Thus, even though the horns did not respond to a decidualizing stimulus after antiprogesterone treatment there was about a $50 \%$ reduction in their oestrogen receptor concentrations compared with the

Table 1. Effects of anti-progesterone antibody (DB3) and progesterone receptor antagonists (RU486 and ZK299) on oil-induced deciduomata formation in mice

\begin{tabular}{lcccc}
\hline Treatment & $\begin{array}{c}\text { Number } \\
\text { of mice }\end{array}$ & $\begin{array}{c}\text { Net gain in } \\
\text { uterine mass }(\mathrm{mg})\end{array}$ & $\begin{array}{c}\text { Percentage } \\
\text { inhibition }\end{array}$ & $\begin{array}{c}\text { Ovary mass } \\
(\mathrm{mg})\end{array}$ \\
\hline $\begin{array}{l}\text { Control } \\
\text { Systemic treatment }\end{array}$ & 8 & $294.5 \pm 55.6$ & 0 & $5.0 \pm 0.3$ \\
$\quad$ DB3 & 6 & $0.8 \pm 2.7^{\mathrm{a}}$ & 99.8 & $4.8 \pm 0.4$ \\
RU486 & 6 & $3.3 \pm 2.8^{\mathrm{a}}$ & 98.9 & $5.5 \pm 0.3$ \\
ZK299 & 5 & $6.0 \pm 1.3^{\mathrm{a}}$ & 98.0 & $4.4 \pm 0.4$ \\
Local treatment & 6 & $9.7 \pm 3.8^{\mathrm{a}}$ & 96.7 & $4.7 \pm 0.4$ \\
RU486 & 6 & $3.2 \pm 1.3^{\mathrm{a}}$ & 98.9 & $4.1 \pm 0.5$ \\
ZK299 & & & & \\
\hline
\end{tabular}

Net gain in uterine mass was calculated by subtracting the mass of the control horn from that of the injected horn (wet masses of injected and non-injected horns were $335.2 \pm 52.4$ and $40.8 \pm 5.3 \mathrm{mg}$, respectively). Percentage inhibition was estimated using the following formula:

$$
\% \text { Inhibition }=100-\frac{\text { Gain in mass in treated group }}{\text { Gain in mass in control group }} \times 100
$$

Values are means \pm SEM.

aSignificantly different from the control group $(P<0.001)$. 


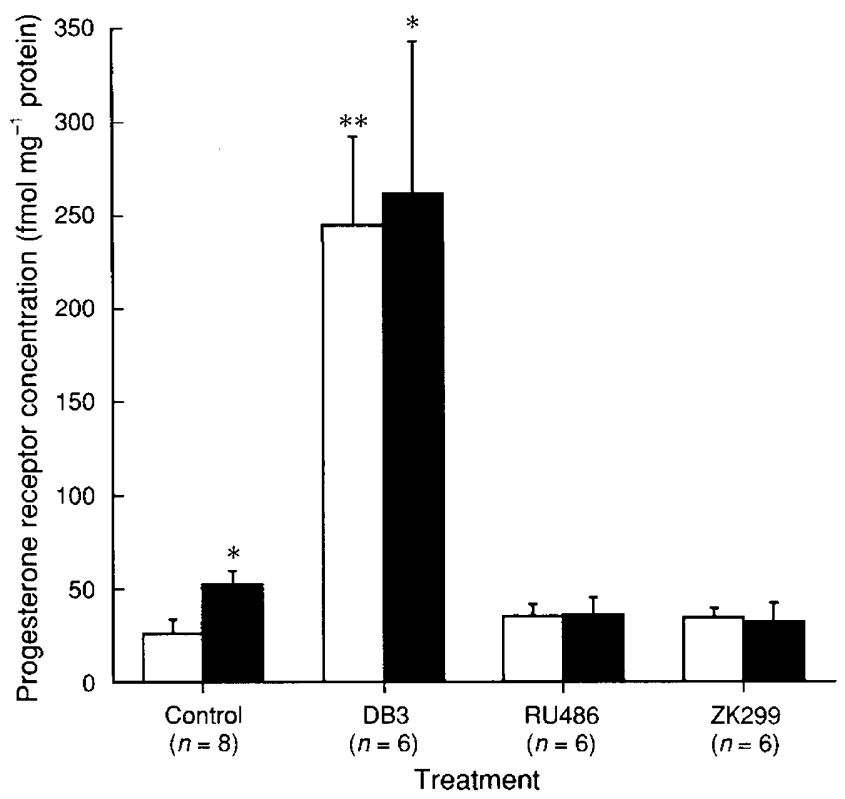

Fig. 1. Effects of anti-progesterone treatment on the concentration of uterine progesterone receptors in mice. Virgin $\mathrm{BALB} / \mathrm{c}$ mice were treated with either progesterone receptor antagonists (RU486 or ZK299; $0.1 \mathrm{mg}$ per animal, s.c.) or a monoclonal antibody against progesterone (DB3; $1.35 \mathrm{mg}$ per animal, i.p.) on day 3 of pseudopregnancy (day 2 for DB3). Control females received $0.1 \mathrm{ml}$ oil. On day 4 , $10 \mu \mathrm{l}$ of sesame oil was injected into the lumen of ( $\boldsymbol{\square})$ the right uterine horn; ( $\square$ ) the left horn was left undisturbed. Uterine samples collected at necropsy on day 7 were homogenized and assayed for

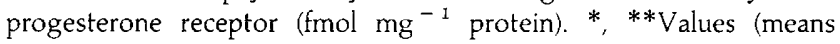
$\pm \mathrm{SEM})$ are significantly different from respective controls $\left({ }^{*} P<0.05\right.$; $* * P<0.01)$

non-injected control horn (Fig. 2). The effects were similar whether RU486 or ZK299 was administered systemically or locally into the uterine lumen (data not shown).

\section{Discussion}

The two models of anti-decidualization illustrate that antagonism of the actions of progesterone either by anti-progesterone immunization or by steroid antagonists is achieved by contrasting effects upon progesterone and oestrogen receptors. Decidualization increases uterine concentrations of progesterone receptors about twofold by day 7 of pseudopregnancy. In the anti-progesterone antibody model, concentrations of progesterone receptors were increased between five- and tenfold in oil-injected and non-injected horns, respectively. No evidence of decidualization, however, was obtained. Thus, increases in concentrations of uterine progesterone receptors do not in themselves predicate decidualization.

Inhibition of decidualization in the antibody model prevents increases in capillary permeability, normally associated with deciduoma formation (Rider ef al., 1985). After antibody treatment at day 2 there is a rapid increase in the circulating concentration of progesterone, the majority of which is bound by antibody with high affinity. Simultaneously, there is a significant fall in uterine progesterone concentrations which

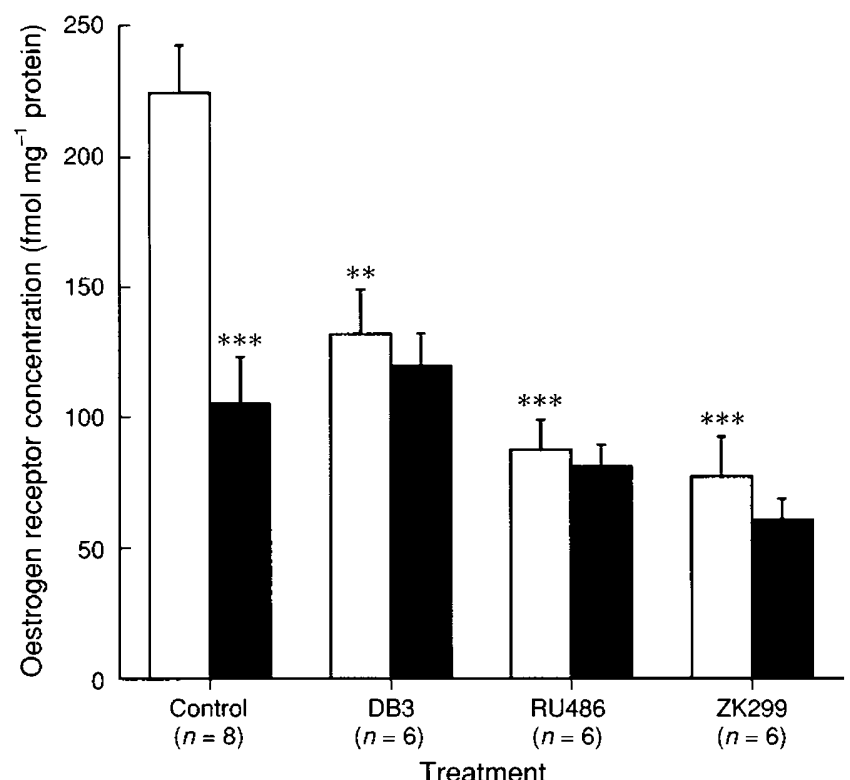

Fig. 2. Effects of anti-progesterone treatment on concentration of uterine oestrogen receptors in mice. Virgin BALB/c mice were treated with either progesterone receptor antagonists (RU486 or ZK299; $0.1 \mathrm{mg}$ per animal, s.c.) or a monoclonal antibody against progesterone (DB3; $1.35 \mathrm{mg}$ per animal, i.p.) on day 3 of pseudopregnancy. Control females received $0.1 \mathrm{ml}$ oil. On day $4,10 \mu \mathrm{l}$ of sesame oil was injected into the lumen of $(\boldsymbol{\square})$ the right uterine horn leaving $(\square)$ the left horn undisturbed. Uterine samples collected at necropsy on day 7 were homogenized and assayed for oestrogen receptor ( $\mathrm{fmol} \mathrm{mg}^{-1}$ protein). $* *, * * *$ Values (means $\pm \mathrm{SEM}$ ) are significantly different from respective controls $(* * P<0.01 ; * * P<0.001)$.

after day 3 return to normal (Nowak et al., 1990), and a marked increase in the expression of progesterone receptor and its mRNA in the endometrial stromal cells as assessed by immunocytochemistry and in situ hybridization (Whyte et al., 1992). Our present results provide further quantitative data that confirm this latter observation.

Increases in endometrial progesterone receptors after passive immunization implicate unopposed oestrogen action (Crombie et al., 1994) or removal of progesterone inhibition (Clark and Markaverich, 1988) as a cause of stimulation. There is a transient increase in uterine epithelial mitoses, a decrease in stromal mitoses (Rider et al., 1986), and a significant reduction in uterine progesterone concentrations at day 2 and day 3 (Nowak ef al., 1990), all consistent with the idea of initial unopposed oestrogen effects. In the antibody model, concentrations of uterine oestrogen receptors were not stimulated, but rather reduced to about $50 \%$ of the control value. An explanation may lie in the initial oestrogen-induced downregulation of the oestrogen receptor followed by the chronic effect of uterine progesterone as its concentration returns to normal values by day 4 . Uterine oestrogen receptor values at day 7 were similar to those found after decidualization in the control group when comparable uterine progesterone concentrations would occur. It is noteworthy that after decidualization there was an eightfold increase in tissue mass and total uterine oestrogen receptor was estimated to be greater than $3000 \mathrm{fmol}$ per oil-injected horn compared with about $700 \mathrm{fmol}$ per non-injected horn. This dilution effect of oestrogen receptor 
concentration by tissue growth after decidualization is well known (Villee et al., 1981) and reflects the synergistic effects of oestrogen and progesterone on oestrogen receptor synthesis and uterine growth.

Anti-progestins RU486 and ZK299 prevent decidualization as reported previously (Crombie et al., 1994; Zhang et al., 1994). In this paper, we demonstrate that the antidecidualization effect is not associated with changes in uterine progesterone receptor concentrations, which remained similar to control values. This result differs markedly from the effect of passive immunization. Oestrogen receptor concentrations decreased by approximately $50 \%$, and values were comparable to those seen in the decidualized horn of control females. These findings contrast with reports that in early human pregnancy RU486 (200 mg) causes a marked increase in immunocytochemical staining of oestrogen receptors, and to a lesser degree in progesterone receptor staining in stromal cells (PerrotApplanat et al., 1994). Similarly, oestrogen receptors in decidua and myometrium increased after RU486 treatment in late pregnant rhesus macaques $\left(20 \mathrm{mg} \mathrm{kg}^{-1}\right.$ day $\left.^{-1}\right)$, presumably because of a decreased inhibition by progesterone on oestrogen receptors (Haluska et al., 1990). However, the relative distribution of these receptors in different uterine compartments was not investigated in the present study. Other workers have found that RU486 (600 mg) in early human pregnancy causes an increase in oestrogen receptor and a decrease in progesterone receptor content of decidua, although results are influenced by dose and time of sampling (Zaytseva et al., 1993). Responses of uterine progesterone and oestrogen receptors to anti-progestins, therefore, are complex, and are influenced by the time course, the species and the protocol adopted.

In summary, decidualization is associated with increased progesterone receptor and decreased oestrogen receptor concentrations. Decidualization can be prevented either by binding of progesterone by antibody or inhibition of the actions of progesterone by receptor antagonists (RU486 and ZK299). Each mechanism is associated with distinct and different effects upon progesterone receptor concentrations. Anti-progesterone antibody produces a significant increase in concentrations of uterine progesterone receptors and a significant decrease in concentrations of oestrogen receptors. These responses suggest that progesterone receptor upregulation is due to an unopposed oestrogen effect shortly after antibody injection. Downregulation of oestrogen receptors probably occurs with chronic progesterone stimulation as its concentration increases and returns to normal after passive immunization. The upregulation of the progesterone receptor in the antibody model occurs predominantly in stromal cells (Whyte et al., 1992) but it fails to increase stromal cell sensitivity to a decidual stimulus. Other endometrial factors, such as the production of HB-EGF (Zhang et al., 1994), angiogenic factors (Smith, 1994), local prostanoid production associated with increased capillary permeability (McRae and Heap, 1988) or leukaemia inhibitory factor (Stewart et al., 1992) are probably missing or deficient. In the second model, steroid anti-progestins have no effect on concentrations of uterine progesterone receptors but reduce oestrogen receptors by more than $50 \%$ through a mechanism(s) that require further clarification. Therefore, lack of stromal cell sensitivity to a decidual stimulus appears to be related less to abnormal uterine progesterone or oestrogen receptor concentrations than to the absence in these two anti-decidualization models of other elements of progesterone-induced receptormediated gene expression. The discovery that antidecidualization effects can be achieved by very different, and counterintuitive receptor responses is important and highly relevant to our understanding of the failure of implantation and the development of new approaches to fertility regulation.

\section{References}

Abrahamson PA and Zorn TMD (1993) Implantation and decidualization in rodents Journal of Experimental Zoology 266 603-628

Anderson J, Clark JH and Peck EJ, Jr (1972) Oestrogen and nuclear binding sites Biochemical Joumal $126561-567$

Bradford M (1976) A rapid and sensitive method for the quantitation of microgram quantities of protein utilizing the principle of protein-dye binding Analytical Biochemistry 72 248-254

Bronson FH, Dagg CP and Snell GB (1966) Reproduction. In Biology of the Laboratory Mouse (2nd Edn) pp 187--204 Ed. EL Green. McGraw-Hill, New York

Clark JH and Markaverich BM (1988) Action of ovarian steroid hormones. In The Physiology of Reproduction pp 675-724 Eds E Knobil, JD Neill, LL Ewing, GS Greenwald, CL Markert and DW Pfaff. Raven Press, New York

Crombie DL, Mukherjee R, McDonnell DP, Hayes IS and Wang M-W (I994) Creatine kinase activity as an indicator of unopposed estrogen action in the mouse uterus associated with anti-progesterone treatment journal of Steroid Biochemistry and Molecular Biology 49 123-129

Ellis ST, Heap RB, Butchart AR, Rider V, Richardson N, Wang M-W and Taussig MJ (1988) Anti-progesterone antibody blocks specifically the establishment of pregnancy in mice Journal of Endocrinology 118 69-80

Finn CA (1977) The implantation reaction. In Biology of the Uterus pp 245-308 Ed. R Wynn. Plenum Press, New York

Glasser SR (1990) Biochemical and structural changes in uterine endometrial cell types following natural or artificial deciduogenic stimuli Trophoblast Research 4 377-416

Haluska GJ, West NB, Novy MJ and Brenner RM (1990) Uterine estrogen receptors are increased by RU486 in late pregnant rhesus macaques but not after spontaneous labor Journal of Clinical Endocrinology and Metabolism 70 181-186

Ho S-M, Damassa D, Kwan PWL, Seto HSK and Leav I (1985) Androgen receptor levels and androgen contents in the prostate lobes of intact and testosterone-treated Noble rats Journal of Andrology $6279-290$

Hsueh AJW, Peck EJ, Jr and Clark JH (1976) Control of uterine estrogen receptor levels by progesterone Endocrinology 98 438-444

Kraus WL and Katzenellenbogen BS (1993) Regulation of progesterone receptor gene expression and growth in the rat uterus: modulation of estrogen actions by progesterone and sex steroid hormone antagonists Endocrinology 132 2371-2379

McDonnell DP, Vegeto E and Gleeson MAG (1993) Nuclear hormone receptors as targets for new drug discovery Bio/Technology 11 1256-1261

McRae AC and Heap RB (1988) Uterine vascular permeability, blood flow and extraceliular fluid space during implantation in rats Joumal of Reproduction and Fertility $\mathbf{8 2} 617-625$

Manni A, Baker R, Arafah BM and Pearson OH (1981) Uterine oestrogen and progesterone receptors in the ovariectomized rat Journal of Endocrinology $\mathbf{9 1}$ 281-287

Nowak RA, Wang M-W, Hamon MH, Lamb DJ, Bullock DW and Heap RB (1990) Effect of passive immunization against progesterone on its distribution in circulation and tissues of mice Journal of Reproduction and Fertility $\mathbf{8 9}$ $671-679$

Pavlik EJ and Coulson PB (1976) Modulation of estrogen receptors in four different target tissues: differential effects of estrogen vs progesterone Journal of Steroid Biochemistry 7 369-376

Perrot-Applanat M, Deng M, Fernandez $H$, Lelaidier C, Meduri G and Bouchard P (1994) Immunohistochemical localization of estradiol and progesterone receptors in human uterus throughout pregnancy: expression in endometrial blood vessels Journal of Clinical Endocrinology and Metabolism 78 216-224 
Psychoyos A (1973) Endocrine control of egg implantation. In Handbook of Physiology pp 187-215 Eds RO Greep and EG Astwood. American Physiological Society, Washington DC

Rider V, McRae A, Heap RB and Feinstein A (1985) Passive immunization against progesterone inhibits endometrial sensitization in pseudopregnant mice and has antifertility effects which are reversible by steroid treatment Journal of Endocrinology 104 153-158

Rider V, Wang MY, Finn C, Heap RB and Feinstein A (1986) Antifertility effect of passive immunization against progesterone is influenced by genotype Journal of Endocrinology 108 117-121

Roblero LS and Croxatto HB (1991) Effect of RU486 on development and implantation of rat embryos Molecular Reproduction and Development 29 342-346

Shupnik MA, Gordon MS and Chin WW (1989) Tissue-specific regulation of rat estrogen receptor mRNAs Molecular Endocrinology 3 660-665

Smith SK (1994) Growth factors in the human endometrium Human Reproduction 9 936-946

Stewart CL, Kaspar P, Brunet LJ, Bhatt H, Gadi I, Köntgen F and Abbondanzo SJ (1992) Blastocyst implantation depends on maternal expression of leukaemia inhibitory factor Nature $35976-79$

Tang B, Guller S and Gurpide E (1994) Mechanism of human endometrial stromal cell decidualization Annals of the New York Academy of Sciences 734 19-25

Truss M, Bartsch J and Beato M (1994) Antiprogestins prevent progesterone receptor binding to hormone responsive elements in vivo Proceedings of the National Academy of Sciences USA $9111333-11337$
Villee CA, Armstrong EG, Jr, Talley DJ and Hoshiai H (1981) Decidual cell function: role of steroid hormones and their receptors. In Cellular and Molecular Aspects of Implantation pp 241-252 Eds SR Glasser and DW Bullock. Plenum Press, New York

Vinijsanun A and Martin L (1990) Effects of progesterone antagonists RU486 and ZK98734 on embryo transport, development and implantation in laboratory mice Reproduction, Fertility and Development 2 713-727

Wang M-W and Heap RB (1992) Vaccination against pregnancy Oxford Reviews of Reproductive Biology 14 101-140

Wang X-N, Das SK, Damm D, Klagsbrun M, Abraham JA and Dey SK (1994) Differential regulation of heparin-binding epidermal growth factor-like growth factor in the adult ovariectomized mouse uterus by progesterone and estrogen Endocrinology 135 1264-1271

Whyte A, Wang M-W, Cheng JT and Heap RB (1992) Proto-oncogene erbA expression and increased abundance of progesterone receptors in the mouse uterus after passive immunization against progesterone before implantation Journal of Reproductive Immunology 22 153-172

Zaytseva TS, Goncharova VN, Morozova MS, Astakhova TM, Manuilova IA and Pankov YA (1993) The effect of RU486 on progesterone and oestrogen receptor concentration in human decidua on early pregnancy Human Reproduction 8 1288-1292

Zhang Z, Funk C, Glasser SR and Mulholland J (1994) Progesterone regulation of heparin-binding epidermal growth factor-like growth factor gene expression during sensitization and decidualization in the rat uterus: effects of the antiprogestin, ZK98.299 Endocrinology 135 1256-1263 